\title{
LEGALITAS PENDIRIAN RUMAH IBADAT BERDASARKAN PERATURAN BERSAMA MENTERI AGAMA DAN MENTERI DALAM NEGERI NOMOR 9 TAHUN 2006
}

\author{
Oleh: Ardiansah \\ Dosen Magister Ilmu Hukum Universitas Lancang Kuning \\ Alamat Kantor JI. Yos Sudarso Km 8 Rumbai, Pekanbaru \\ Email: ardiansyah2000@yahoo.com
}

\begin{abstract}
Abstrak
Pemerintah telah mengeluarkan Peraturan Bersama Menteri Agama dan Menteri Dalam Negeri (PBM) Nomor 9 Tahun 2006 mengenai Pendirian Rumah Ibadat. Peraturan ini bertujuan untuk menciptakan kerukunan umat beragama. Namun, pemberlakuan peraturan ini justeru telah memicu ketegangan dan konflik antara pemeluk agama. Kenyataan ini menunjukkan adanya problem hukum yang penting untuk diteliti. Jenis penelitian yang digunakan ialah penelitian hukum normatif. Penelitian ini menggunakan pendekatan perundang-undangan dan pendekatan konseptual. Hasil penelitian menunjukkan bahwa PBM mengatur secara khusus dua hal yang saling berkaitan pembinaan kerukunan umat beragama melalui pembentukan Forum Kerukunan Umat Beragama dan prosedur pendirian rumah ibadat. Peraturan Bersama Menteri Agama dan Menteri Dalam Negeri ini lebih rinci mengatur kewenangan pemeliharaan kerukunan umat beragama, mekanisme perizinan rumah ibadat, dan penyelesaian bila terjadi konflik. Keberadaan regulasi yang baru tersebut diharapkan mampu mencegah potensi konflik berkaitan dengan pendirian rumah ibadah, diantaranya persyaratan pendirian rumah ibadah, proses perizinan rumah ibadat yang sering berlarut-larut, penyalahgunaan rumah tinggal yang difungsikan sebagai rumah ibadat, dan sebagainya. PBM mengatur penyelesaian masalah melalui jalur musyawarah dan pengadilan. Apabila kedua jalur penyelesaian tersebut tidak bisa menyelesaikan perselisihan maka perlu ditingkatkan level pengaturan rumah ibadat menjadi undang-undang. Problem pendirian rumah ibadat dapat diselesaikan secara komprehensif jika terdapat suatu undang-undang yang mengatur tentang pendirian rumah ibadat. Solusi komprehensif ini perlu dilakukan agar tidak terjadi lagi konflik dan disharmonis antar penganut berbagai agama.
\end{abstract}

\begin{abstract}
The Government has issued a Joint Regulation of Religious Affairs and Minister of the Interior (PBM) No. 9 of 2006 on the Establishment of House of Worship. This regulation aims to create religious harmony. However, enforcement of this regulation precisely has sparked tension and conflict between religions. This fact shows the legal problems that are important to study. This type of research is a normative legal research. This study uses the approach of legislation and conceptual approaches. The results showed that the PBM specifically regulate two things are interrelated fostering religious harmony through the establishment of the Forum for Religious Harmony and procedures for establishing a synagogue. Joint Regulation of Religious Affairs and Minister of the Interior this in more detail for the authorities of the maintenance of religious harmony, the licensing mechanism of the synagogue, and the completion of the event of conflict. The existence of the new regulation is expected to prevent potential conflicts related to
\end{abstract}


the establishment of houses of worship, including requirements for the establishment of houses of worship, the synagogue that the licensing process is often protracted, misuse of residential houses which functioned as a synagogue, and so on. PBM set problem resolution through consultation and trial. When the two lines of the settlement could not resolve the dispute then need to be improved level of adjustment synagogue became law. Problem establishment of the synagogue can be resolved in a comprehensive manner if there is a law governing the establishment of the synagogue. This comprehensive solution needs to be done in order to avoid further conflicts and disharmonis between followers of different religions.

\section{Kata kunci: Pendirian Rumah Ibadat, Peraturan Bersama Menteri, Umat Beragama}

\section{Pendahuluan}

Setiap agama besar yang ada di Indonesia dilindungi oleh undang-undang yang berlaku dan agama-agama itu memiliki hak yang sama untuk hidup dan berkembang. Setiap umat beragama berhak menyiarkan agama dan mendirikan rumah ibadah. Tetapi, kalau tidak ada aturanya atau ada aturan, tetapi dilanggar maka terjadi benturan atau konflik antar umat beragama itu sendiri. ${ }^{1}$

Keberagaman yang ada tersebut menciptakan polarisasi dalam pengelompokkan atau kelas sosial masyarakat. Beragamnya jenis suku, ras dan agama maka tidak terhindarkan munculnya problem sosial terutama kaitannya dalam kehidupan beragama. Kondisi kota yang sedang berkembang tidak terhindarkan banyaknya potensi konflik yang terjadi. Tidak jarang terjadi perselisihan di masyarakat yang mengetengahkan isu atau simbol agama seperti pendirian rumah ibadah. Permasalahan itu muncul antara lain adanya pendirian rumah ibadah yang tidak mempunyai izin, penggunaan fasilitas umum sebagai tempat ibadah, dan munculnya protes warga terhadap keberadaan suatu rumah ibadah. ${ }^{2}$
Pemerintah telah mengeluarkan Peraturan Bersama MenteriAgama dan Menteri Dalam Negeri (PBM) Nomor 9 Tahun 2006 dan Nomor 8 Tahun 2008 tentang Pedoman Pelaksanaan Tugas Kepala Daerah/Wakil Kepala Daerah dalam Pemeliharaan Kerukunan Umat Beragama, Pemberdayaan Forum Kerukunan Umat Beragama, dan Pendirian Rumah Ibadat. Namun, pemberlakuan Peraturan Bersama Menteri Agama dan Menteri Dalam Negeri tersebut telah memicu tingginya angka penutupan, penyegelan dan pembakaran rumah ibadah yang semakin tinggi angkanya pada tahun $2010 .^{3}$

Pendirian rumah ibadah yang tidak mengikuti aturan yang berlaku cenderung menjadi pemicu ketegangan, bahkan konflik antar pemeluk agama di Indonesia. Mursyid Ali menyebutkan tujuh faktor pemicu ketegangan yang bisa menimbulkan konflik antar pemeluk agama, yakni pendirian rumah ibadah, penyiaran agama, bantuan luar negeri, perkawinan beda agama, perayaan hari besar keagamaan, penodaan agama baik yang dilakukan oleh seseorang maupun kelompok orang, dan kegiatan aliran sempalan, yang

\footnotetext{
${ }^{1}$ Aslati, Optimalisasi Peran FKUB Dalam Menciptakan Toleransi Beragama di Kota Pekanbaru, Jurnal Toleransi: Media Komunikasi Umat Beragama, Volume 6, Nomor 2 Juli-Desember 2014, hlm. 188.

2Ibid, hlm. 189.

${ }^{3}$ Ahmad Subakir dkk, Potret Buram Kebebasan Beragama, (Yogyakarta: Nadi Pustaka-STAIN Kediri Press, 2010), hlm. 7.
} 
dilakukan seseorang atau sekelompok orang yang didasarkan keyakinan terhadap agama tertentu secara menyimpang dari agama bersangkutan. Ahsanul Khalikin menyebut empat faktor pemicu ketegangan, bahkan konflik antar pemeluk agama, yakni pendirian rumah ibadah, penyiaran agama, masalah intern agama, dan penodaan agama. ${ }^{4}$

Muhith A. Karim dkk menyebut lima hal yang menyebabkan ketidakrukunan umat beragama, yaitu pendirian rumah ibadah; penyiaran agama; masalah intern agama; penodaan terhadap agama; dan kegiatan aliran sempalan. ${ }^{5}$ Sementara Titik Suwariyati menyebutkan empat hal pemicu konflik antar maupun intern umat beragama, yaitu pendirian rumah ibadah; penyiaran agama; penguburan jenazah; peringatan hari-hari besar keagamaan. ${ }^{6}$

Beberapa pendapat tersebut menunjukkan adanya problem hukum mengenai pendirian rumah ibadah di Indonesia. Problem hukum pendirian rumah ibadah tersebut penting diteliti secara intens agar dapat dirumuskan solusinya untuk mewujudkan kerukunan umat beragama.

Tulisan ini berupaya menganalisis bagaimana pengaturan tentang pendirian rumah ibadat, bagaimana pengaturan pendirian rumah ibadat, dan bagaimana pula penyelesaian perselisihan mengenai pendirian rumah yang bertentangan dengan Peraturan Bersama
Menteri Agama dan Menteri Dalam Negeri Nomor 9 dan Nomor 8 Tahun 2006.

\section{Metode Penelitian}

Penelitian ini termasuk jenis penelitian hukum normatif. Penelitian hukum normatif adalah penelitian hukum yang dilakukan dengan cara meneliti bahan pustaka. Dalam penelitian hukum normatif, bahan pustaka merupakan data dasar yang dalam ilmu penelitian yang digolongkan sebagai data sekunder. ${ }^{7}$ Penelitian hukum normatif mengkaji tentang hukum tertulis dari berbagai aspek teori, sejarah, perbandingan, struktur dan komposisi, lingkup dan materi, konsistensi, penjelasan umum dan pasal demi pasal, formalitas dan kekuatan mengikat suatu undang-undang serta bahasa hukum yang digunakan. ${ }^{8}$ Penelitian hukum normatif juga mengkaji tentang asas-asas hukum dan sistematika hukum. ${ }^{9}$ Penelitian hukum normatif bisa juga mengkaji tentang inventarisasi hukum positif, penemuan asas hukum, dan penemuan hukum in concreto. ${ }^{10}$

Pendekatan dalam penelitian ini menggunakan pendekatan perundangundangan (statue approach), yaitu pendekatan yang dilakukan menelaah semua undangundang dan regulasi yang bersangkut paut dengan isu hukum yang ditangani dan pendekatan konseptual (conceptual approach), yaitu mempelajari pandangan dan doktrin

${ }^{4}$ Mursyid Ali dalam Ahsanul Khalikin, Peta Kerukunan Di DKI Jakarta, (Jakarta: Balitbang dan Diklat, 2001), hlm. 79-80.

${ }^{5}$ Muhith A. Karim, dkk, Peta Kerukunan Jawa Timur, (Jakarta: Balitbang dan Diklat Depag, 2001), hlm. 241-243.

${ }^{6}$ Titik Suwariyati, Peta Kerukunan di Yogyakarta, (Jakarta: Balitbang dan Diklat, 2001), hlm. 172-175.

${ }^{7}$ Soejono Soekanto dan Sri Mamudji, Penelitian Hukum Normatif Suatu Tinjauan Singkat, Cetakan XI, (Jakarta: Raja Grafindo Persada, 2009), hlm. 234-242.

${ }^{8}$ Abdul Kadir Muhammad, Hukum dan Penelitian Hukum, (Bandung: Citra Aditya Bakti, 2004), hlm. 132.

${ }^{9}$ Soerjono Soekanto \& Sri Mamudji, Penelitian Hukum Normatif Suatu Tinjauan Singkat, (Jakarta: Rajawali Pers, 2007), hlm. 14.

${ }^{10}$ Burhan Ashofa, Metode Penelitian Hukum, (Jakarta: Rineka Cipta, 2006), hlm. 14. 
dalam ilmu hukum serta konsep asas hukum yang relevan. ${ }^{11}$

Penelitian hukum normatif ini dilakukan untuk menghasilkan ketajaman analisis hukum yang didasarkan pada doktrin dan norma-norma yang telah ditetapkan dalam sistem hukum, baik yang telah tersedia sebagai bahan hukum maupun yang dicari sebagai bahan kajian guna memecahkan problem hukum faktual. ${ }^{12}$

\section{Pembahasan}

\section{Kedudukan Agama Dalam Konstitusi Indonesia}

Pasal 29 Undang-Undang Dasar Negara Republik Indonesia Tahun 1945 (UUD 1945) mengatur mengenai agama. ${ }^{13}$ Pasal 29 Ayat (1) menyatakan bahwa Negara berdasar Ketuhanan Yang Maha Esa. Sementara Ayat (2) menyatakan bahwa Negara menjamin kemerdekaan tiap-tiap penduduk untuk memeluk agamanya masing-masing dan untuk beribadat menurut agama dan kepercayaannya itu.

Ketentuan tersebut menunjukkan bahwa negara tidak merujuk kepada agama tertentu dan tidak pula memisahkan urusan agama dan negara. Negara bertanggung jawab atas keberadaan agama, kehidupan beragama, dan kerukunan hidup beragama. Hubungan antara agama dan negara dapat dilihat dari keberadaan institusi-institusi keagamaan, hukum yang berkaitan dengan agama, dan kebijakan yang berkaitan kehidupan keagamaan. ${ }^{14}$

Indonesia bukan negara agama. Indonesia bukan pula negara yang mengakui salah satu agama resmi negara. Indonesia adalah negara Pancasila yang memperlakukan sama berbagai agama. Tidak ada agama istimewa yang lebih dominan di antara berbagai agama. Pemerintah Indonesia berperanan penting dalam mengurusi agama, tetapi tidak menjadikan negara Indonesia sebagai negara agama. ${ }^{15}$

Indonesia menjamin keberadaan agama, seperti Islam, Kristen, Buddha, Hindu, dan Kong $\mathrm{Hu} \mathrm{Cu} .{ }^{16}$ Indonesia menempatkan ajaran dan nilai agama di dalam kehidupan bernegara, sebagaimana tercantum di dalam sila pertama Pancasila dan Pembukaan UUD 1945. Penganut agama Islam dan non Islam tidak merasa ada hambatan mengamalkan ajaran agamanya. ${ }^{17}$ Pengaturan yang terdapat dalam UUD 1945 bertentangan arah dengan sekularisme. ${ }^{18}$ Secara konsti-

${ }^{11}$ Peter Mahmud Marzuki, Penelitian Hukum,(Jakarta: Kencana Prenada Media, 2011), hlm. 24.

12Johnny Ibrahim, Teori dan Metodologi Penelitian Hukum Normatif, (Surabaya: Bayu Media Publishing, 2006), hlm. 73.

${ }^{13}$ Undang-Undang Dasar Negara Republik Indonesia Tahun 1945 lazim disingkat UUD 1945.

${ }^{14}$ Ahmad Sukadja, Piagam Madinah dan Undang-Undang Dasar 1945: Kajian Perbandingan tentang Dasar Hidup Bersama dalam Masyarakat yang Majemuk, (Jakarta: Universitas Indonesia Press, 1995), hlm. 146.

${ }^{15} \mathrm{lbid}$.

${ }^{16}$ Menurut hasil sensus tahun 2010 Penduduk Indonesia berjumlah 237.641.326. Pemeluk Islam 87,18\%, Protestan 6,96\%, Katolik 2,9\%, Hindu 1,69\%, Budha 0,72\%, Kong Hu Cu 0,05\%, agama lainnya 0,13\%, dan tidak menyatakan agama $0,38 \%$. Lihat http://id.wikipedia.org/wiki/Agama_di_Indonesia, diakses tanggal 26 Juni 2016.

${ }^{17}$ Nasaruddin Umar, Antara Negara \& Agama Negara, hlm. 4. Lihat http://kemenag.go.id/file/dokumen/ AntaraNegara.pdf, diakses tanggal 12 Juni 2016.

${ }^{18}$ Sekularisme adalah faham, pandangan dan gerakan moral yang tidak berdasarkan ajaran agama. Sekularisme memandang urusan dunia dan agama terpisah. Dalam implementasinya, tingkah laku manusia dalam masyarakat harus dipisahkan dari agama. Agama hanya dipandang sebagai urusan seseorang dengan Tuhannya. Lihat James Hasting (ed), Encyclopedia of Religion and Ethics, Volume XI, (New York: Charles Scribner's Son, tt), hlm. 347-349. 
tusional, beragama dan beriman dijamin oleh negara. ${ }^{19}$

\section{Kebebasan Beragama Dalam Konstitusi Indonesia}

Kebebasan beragama termaktub dalam Pasal 28E Ayat (1) dan (2) UUD 1945, Pasal 28I Ayat (1) UUD 1945, Pasal 28J Ayat (2) UUD 1945, dan Pasal 29 Ayat (1) dan (2) UUD 1945. Pasal 28E Ayat 1 UUD 1945 menyebutkan bahwa "Setiap orang bebas memeluk agama dan beribadat menurut agamanya, memilih pendidikan dan pengajaran, memilih pekerjaan, memilih kewarganegaraan, memilih tempat tinggal di wilayah negara dan meninggalkannya, serta berhak kembali”. Pasal 28E Ayat (2) UUD 1945 menyebutkan bahwa "Setiap orang berhak atas kebebasan meyakini kepercayaan, menyatakan pikiran, dan sikap sesuai dengan hati nuraninya". Pasal 28I Ayat (1) UUD 1945 menyebutkan bahwa "Hak untuk hidup, hak untuk tidak disiksa, hak kemerdekaan pikiran dan hati nurani, hak beragama, hak untuk tidak diperbudak, hak untuk diakui sebagai pribadi di hadapan hukum, dan hak untuk tidak dituntut atas dasar hukum yang berlaku surut adalah hak asasi manusia yang tidak dapat dikurangi dalam keadaan apapun". Pasal 28J Ayat (2) UUD 1945 menyebutkan bahwa "Dalam menjalankan hak dan kebebasannya, setiap orang wajib tunduk kepada pembatasan yang ditetapkan dengan undang-undang dengan maksud semata-mata untuk menjamin pengakuan serta penghormatan atas hak dan kebebasan orang lain dan untuk memenuhi tuntutan yang adil sesuai dengan pertimbangan moral, nilai-nilai agama, keagamaan, dan ketertiban umum dalam suatu masyarakat demokratis". ${ }^{20}$

Pada bagian lain, Pasal 29 Ayat (1) UUD 1945 menyebutkan bahwa "Negara berdasarkan atas Ketuhanan Yang Maha Esa". Pasal 29 Ayat (2) UUD 1945 menyebutkan bahwa "Negara menjamin kemerdekaan tiap-tiap penduduk untuk memeluk agamanya masingmasing dan untuk beribadat menurut agamanya dan kepercayaannya itu". ${ }^{21}$

Dari beberapa pasal tersebut tampak adanya jaminan kebebasan beragama dalam UUD 1945. Namun, tidak dijelaskan secara terperinci peruntukan kebebasan beragama. Ketiadaan peruntukan kebebasan beragama dalam UUD 1945 tersebut telah mengakibatkan timbulnya berbagai penafsiran mengenai pendirian rumah ibadat. Sebagian penganut agama menafsirkan pendirian rumah ibadat sebagai pelaksanaan kebebasan beragama.

Ketidakjelasan peruntukan kebebasan beragama telah dimanfaatkan oleh penganut agama non Islam untuk mendirikan rumah ibadat tanpa memiliki izin dari Pemerintah Daerah dengan alasan kebebasan beragama yang dijamin UUD 1945. Kenyataan ini tentu meresahkan penganut agama Islam dan berpotensi menimbulkan konflik antara penganut agama.

\section{Pengaturan Pendirian Rumah Ibadat}

Pemerintah berupaya menciptakan kerukunan umat beragama sesuai dengan tuntutan masyarakat pada masanya yang memiliki kekuatan dan kelemahannya masingmasing. ${ }^{22}$ Pada era Orde Lama, pemerintah berupaya membangun kerukunan nasional,

${ }^{19}$ Ahmad Sukardja, Piagam Madinah dan...Op. Cit., hlm. 94-95.

${ }^{20}$ Undang-Undang Dasar Negara Republik Indonesia Tahun 1945, hlm. 26-29. Lihat http://www.mahkama hkonstitusi.go.id/public/content/profil/kedudukan/UUD_1945_Perubahan\%204.pdf, diakses tanggal 21 Juni 2016.

${ }^{21} \mathrm{lbid}, \mathrm{hlm} .30$.

${ }^{22}$ Haidlor Ali Ahmad (Ed), Survey Nasional Kerukunan Umat Beragama di Indonesia, (Jakarta: Puslitbang Kehidupan Keagamaan Badan Litbang dan Diklat Kementerian Agama RI, 2013), hlm. xiv. 
termasuk kerukunan keagamaan. Selain, itu kebijakan politik demokrasi terpimpin dan Nasakom dikembangkan, meskipun dalam perjalanannya terdapat penentangan. Pada era Orde Baru, pemerintah berupaya mempertahankan keutuhan bangsa dan kerukunan umat beragama dengan cara mempertahankan Pancasila sesuai aslinya. Pada masa ini, kebijakan politik demokrasi terpimpin diganti dengan demokrasi pancasila. Kebijakan asas tunggal Pancasila diberlakukan untuk semua ormas dan orpol, meskipun pada akhirnya kebijakan ini kerapkali menuai kecaman.

Dalam perkembangannya, pada era reformasi, pemerintah berupaya mempertahankan keutuhan bangsa dan kerukunan umat beragama dengan tetap mempertahankan Pancasila sesuai dengan aslinya. UndangUndang Dasar 1945 diamandemen untuk merespon perkembangan zaman. Pada era ini, kebijakan politik demokrasi lebih liberal dan otonomi daerah diberlakukan. Kebijakan pembinaan agama tetap dilakukan secara sentralistis. ${ }^{23}$

Dalam pandangan Atho'Mudhzhar, Kementerian Agama selaku penanggung jawab pembinaan kerukunan keagamaan telah lama menerbitkan regulasi dan mengembangkan konsep-konsep kebijakan yang bersifat normatif dan akademik. Pada aspek regulasi, era Menteri Agama KH Moh. Dahlan, diterbitkan Surat Keputusan Bersama (SKB) Menteri Agama dan Menteri Dalam Negeri, tentang Pelaksanaan Tugas Aparatur Pemerintahan Dalam Menjamin Ketertiban dan Kelancaran Pelaksanaan Pengembangan dan Ibadat Agama oleh Pemeluk-Pemeluknya. Pada era Menteri
Alamsyah Ratu perwira-negara diterbitkan Keputusan Menteri Agama tentang Penyiaran Agama dan Bantuan Luar Negeri, yang kemudian diperkuat dengan SKB Menteri Agama dan Menteri Dalam Negeri tentang Tatacara Pelaksanaan Penyiaran Agama dan Bantuan Luar Negeri kepada Lembaga Keagamaan di Indonesia. Pada masa Menteri Agama Tarmizi Taher, diterbitkan Surat Keputusan tentang Petunjuk Pelaksanaan Penanggulangan Kerawanan Kerukunan Hidup Umat Beragama. Kemudian pada masa Menteri Agama Maftuh Basuni, diterbitkan Peraturan Bersama Menteri Agama dan Menteri Dalam Negeri, tentang Pedoman Pelaksanaan Tugas Kepala Daerah/Wakil Kepala Daerah Dalam Pemeliharaan Kerukunan Umat Beragama, Pemberdayaan Forum Kerukunan Umat Beragama dan Pendirian Rumah Ibadat. ${ }^{24}$

Kerukunan umat beragama adalah keadaan hubungan sesama umat beragama yang dilandasi toleransi, saling pengertian, saling menghormati, menghargai kesetaraan dalam pengamalan ajaran agamanya dan kerja sama dalam kehidupan bermasyarakat, berbangsa dan bernegara di dalam Negara Kesatuan Republik Indonesia berdasarkan Pancasila dan Undang-undang Dasar Republik Indonesia Tahun $1945 .{ }^{25}$ Kerukunan antar umat beragama ini bisa terwujud jika ada toleransi saling memahami, menghormati, menghargai, kesetaraan dalam pengamalan ajaran agamanya masing-masing dan membangun kerja sama yang positif dan produktif. ${ }^{26}$

Pemerintah mengeluarkan kebijakan melalui Surat Keputusan Bersama (SKB) Menteri Dalam Negeri dan Menteri Agama

23 Ibid.

${ }^{24}$ Atho'Mudhzhar, dalam Abdurrahman Mas'ud dkk (ed), Kerukunan Umat Beragama dalam Sorotan: Refleksi dan Evaluasi 10 Tahun Kebijakan danProgram Pusat Kerukunan Umat Beragama, (Jakarta: Sekretariat Jenderal Kementerian Agama, 2011), hlm. 19-38.

${ }^{25}$ Bab I Pasal 1 Peraturan Bersama Menteri Agama dan Menteri Dalam Negeri Nomor 9 Tahun 2006 dan Nomor 8 Tahun 2006. 
Nomor 1 Tahun 1969 tentang Pelaksanaan Tugas Aparatur Pemerintah dalam Menjamin Ketertiban dan Kelancaran Pelaksanaan Pengembangan dan Ibadat Agama oleh Pemeluk-Pemeluknya dan Surat Keputusan (SK) Menteri Agama Nomor 70 Tahun 1978 tentang Pedoman Penyiaran Agama oleh Menteri agama bertujuan untuk mengelola kehidupan umat beragama di Indonesia. Surat Keputusan ini merekomendasikan kepada pemerintah daerah dan departemen setempat untuk membimbing, mengarahkan dan mengawasi serta menyelesaikan pertentangan yang mungkin timbul secara adil dan tidak memihak. Kebijakan ini mencerminkan adanya campur tangan negara terhadap kehidupan umat beragama. Kebijakan ini mengatur secara praksis kehidupan umat beragama di seluruh Indonesia. $^{27}$

Keberadaan SKB tersebut ternyata masih dirasa cukup memojokkan bagi kaum minoritas, terlebih umat Kristen-Katolik yang memiliki banyak sekte. Aturan ini dianggap membatasi. Bagi umat Islam yang kebetulan secara komposisi minoritas disebuah wilayah juga terkena dampak dari SKB ini. Dengan alasan umat Kristen dianggap yang paling dirugikan dengan diberlakukannya SKB ini maka melalui Persekutuan Gereja Indonesia, dilontarkan usulan perlunya pemerintah mencabut SKB tersebut. $^{28}$

Praktik di lapangan menunjukkan pemberlakuan SKB tersebut menemui berbagai kendala. Hal ini terjadi karena beberapa faktor, antara lain materi SKB terdapat kalimat multitafsir sehingga tidak ada kejelasan mengenai siapa yang disebut sebagai pemerintah daerah, siapa yang disebut sebagai pejabat pemerintah dibawahnya yang dikuasakan untuk itu, dan siapa yang disebut sebagai organisasi keagamaan, dan ulama atau rohaniawan setempat. ${ }^{29}$

Pro dan kontra di tengah masyarakat terkait keberadaan SKB Nomor 1 Tahun 1969 juga terlihat diberbagai media massa. Sebagian pemuka agama mengusulkan SKB tersebut dicabut, sementara sebagian pemuka agama lainnya mengusulkan untuk tetap dipertahankan. Untuk merespon permasalahan ini, pemerintah (Departemen Agama dan Departemen Dalam Negeri) mengundang para wakil dari masing-masing majelis agama, antara lain Konferensi Gereja-gereja Indonesia, Majelis Ulama Indonesia, Persatuan GerejaGereja Indonesia, Parisada Hindu Dharma Indonesia Pusat (PHDI), dan Perwakilan Umat Budha Indonesia (WALUBI) untuk merevisi Surat Keputusan Bersama Menteri Agama dan Menteri Dalam Negeri Nomor 1 tahun 1969 tentang Pelaksanaan Tugas Aparatur Pemerintah dalam menjamin Ketertiban dan Kelancaran Pelaksanaan pengembangan dan Ibadat Agama oleh Pemeluk-pemeluknya. ${ }^{30}$

Setelah dialog yang intensif selama lebih kurang enam bulan, akhirnya berhasil tercapai

${ }^{26}$ Sigit Dwi Kusrahmaadi, Pentingnya Kerukunan Umat Beragama Dalam Mewujudkan Masyarakat Sipil, ht t p://staff.uny.ac.id/s ites/default/files/Pentingnya\% 20 Kerukunan\%20Umat\%20Beragama\%2018\%20Frb.\%202007\%20No.\%201\%20\%201.pdf, diakses tanggal 21 April 2015.

${ }^{27}$ Baehaqi Imam, Agama dan Relasi Sosial, (Yogyakarta: LKiS, 2005), hlm. 51.

${ }^{28}$ Nur Ahmad, Pesan Dakwah Dalam Menyelesaikan Konflik Pembangunan Rumah Ibadat (Kasus Pembangunan Rumah Ibadah Antara Islam dan Kristen Desa Payaman), Jurnal Fikrah, Volume 1, Nomor 2, Juli-Desember 2013, hIm. 344.

${ }^{29}$ Kustini, Efektifitas Sosialisasi PBM No. 9 dan 8 Tahun 2006, (Jakarta: Balitbang Departemen Agama $\mathrm{RI}, 2009)$, hlm. 2.

${ }^{30}$ Nur Ahmad, Pesan Dakwah...Op.Cit., hlm. 345. 
kesepakatan tanggal 21 Maret 2006 yang dituangkan dalam bentuk Peraturan Bersama Menteri Agama dan Menteri Dalam Negeri Nomor 9 Tahun 2006 dan Nomor 8 tahun 2006 tentang Pedoman Pelaksanaan Tugas Kepala Daerah/Wakil Kepala Daerah dalam memelihara Kerukunan Umat Beragama, Pemberdayaan Forum Kerukunan Umat Beragama, dan pendirian rumah ibadat. ${ }^{31}$

Peraturan ini menggantikan SKB Menteri Dalam Negeri dan Menteri Agama Nomor 1 Tahun 1969 yang dinilai sangat diskriminatif. Peraturan ini bertujuan untuk merespon berbagai keluhan yang dirasakan masyarakat atas maraknya pendirian rumah ibadat umat minoritas di wilayah umat mayoritas dan beragamnya peraturan pendirian rumah ibadat di berbagai daerah pasca pemberlakuan otonomi daerah yang akhirnya membuat umat beragama kesulitan mendirikan rumah ibadat. ${ }^{32}$

Jika SKB Tahun 1969 mengatur kehidupan kerukunan beragama secara umum maka Peraturan Bersama Menteri Agama dan Menteri Dalam Negeri Nomor 9 Tahun 2006 dan Nomor 8 Tahun 2006 mengatur secara khusus dua hal yang saling berkaitan. Pertama, pembinaan kerukunan umat beragama melalui pembentukan Forum Kerukunan Umat Beragama. Kedua, prosedur pendirian rumah ibadat. Peraturan Bersama Menteri Agama dan Menteri Dalam Negeri Nomor 9 Tahun 2006 dan Nomor 8 Tahun 2006 lebih rinci mengatur kewenangan pemeliharaan kerukunan umat beragama, mekanisme perizinan rumah ibadat, dan penyelesaian bila terjadi konflik.

Terbitkannya Peraturan Bersama Menteri Agama dan Menteri Dalam Negeri Nomor 9
Tahun 2006 dan Nomor 8 Tahun 2006 bukan berarti seluruh persoalan pendirian rumah ibadah selesai, karena masih harus diuji pada tingkat implementasi. Regulasi rumah ibadah bukanlah masalah yang berdiri sendiri, tetapi terkait dengan masalah-masalah lain, misalnya soal penyiaran agama dan bantuan asing. Pemerintah mengeluarkan Peraturan Bersama Menteri Agama dan Menteri Dalam Negeri Nomor 9 Tahun 2006 dan Nomor 8 Tahun 2006 sebagai upaya meminimalisir konflik pendirian rumah ibadat.

Sepintas perubahan peraturan tersebut menggambarkan perubahan paradigma pemerintah dalam pengaturan kerukunan beragama. Perubahan paradigma yang dimaksud adalah berubahnya pola berpikir hegemoni kekuasaan terhadap umat beragama kepada pola berpikir partisipatif. Hal tersebut dapat dibaca dengan membandingkan seluruh isi Surat Keputusan Bersama Menteri Dalam Negeri dan Menteri Agama Nomor 1/BER/MdnMag/Tahun 1969 dengan Peraturan Bersama Menteri Agama dan Menteri Dalam Negeri Nomor 9/8 Tahun 2006. ${ }^{33}$

Ada beberapa ketentuan yang memang berbeda dengan ketentuan yang ada pada regulasi sebelumnya. Peraturan Bersama Menteri Agama dan Menteri Dalam Negeri Nomor 9 Tahun 2006 dan Nomor 8 Tahun 2006 mengatur secara terperinci perihal pendirian rumah ibadat Bab IV, Pasal 13-17. Pasal 13 Ayat (1) menyebutkan bahwa "Pendirian rumah ibadat didasarkan pada keperluan nyata dan sungguh-sungguh berdasarkan komposisi jumlah penduduk bagi pelayanan umat beragama yang bersangkutan di wilayah

\section{${ }^{31} \mathrm{Ibid}$.}

${ }^{32} \mathrm{M}$. Agus Noorbani, Pendirian Rumah Ibadat di Kota Cirebon Pasca Pemberlakuan Peraturan Bersama Menteri Agama dan Menteri Dalam Negeri Nomor 9 dan 8 Tahun 2006, Harmoni Jurnal Multi Kultural \& Multi Religius, Volume 14, Desember 2015, hlm. 10-11.

${ }^{33}$ Abdi Kurnia Djohan, Analisis dan Perbandingan Pengaturan Kerukunan Umat Beragama di Indonesia, (Jakarta: Universitas Indonesia, 2010), hlm. 80. 
kelurahan/desa". Pasal 13 Ayat (2) menyebutkan bahwa "Pendirian rumah ibadat sebagaimana dimaksud pada Ayat (1) dilakukan dengan tetap menjaga kerukunan umat beragama, tidak mengganggu ketenteraman dan ketertiban umum, serta mematuhi peraturan bangunan gedung perundangundangan". Pasal 13 Ayat (3) menyebutkan bahwa "Dalam hal keperluan nyata bagi pelayanan umat beragama di wilayah kelurahan/ desa sebagaimana dimaksud Ayat (1) tidak terpenuhi, pertimbangan komposisi jumlah penduduk digunakan batas wilayah kecamatan atau kabupaten/ kota atau provinsi".

Pasal 14 mengatur tentang syarat administrasi dan dukungan komposisi jemaat dan warga setempat dalam pendirian rumah ibadah. Pasal 14 Ayat (1) menyebutkan bahwa "Pendirian rumah ibadat harus memenuhi persyaratan administratif dan persyaratan teknis bangunan gedung". Pasal 14 Ayat (2) menyebutkan bahwa "Selain memenuhi persyaratan sebagaimana dimaksud pada Ayat (1) pendirian rumah ibadat harus memenuhi persyaratan khusus meliputi: (a) daftar nama dan Kartu Tanda Penduduk pengguna rumah ibadat paling sedikit 90 (sembilan puluh) orang yang disahkan oleh pejabat setempat sesuai dengan tingkat batas wilayah sebagaimana dimaksud dalam Pasal 13 Ayat (3), (b) dukungan masyarakat setempat paling sedikit 60 (enam puluh) orang yang disahkan oleh lurah/kepala desa; (c) Rekomendasi tertulis kepala kantor departemen agama kabupaten/kota; dan (d) Rekomendasi tertulis FKUB kabupaten/kota". Pasal 14 Ayat (3) menyebutkan bahwa "Dalam hal persyaratan sebagaimana dimaksud pada Ayat (2) huruf a terpenuhi sedangkan persyaratan huruf $b$ belum terpenuhi, pemerintah daerah berkewajiban memfasilitasi tersedianya lokasi pembangunan rumah ibadat". ${ }^{34}$

Keberadaan regulasi yang baru tersebut diharapkan mampu menjembatani dan mencegah potensi konflik berkaitan dengan pendirian rumah ibadah. Potensi konflik muncul karena beberapa persoalan, diantaranya belum adanya penjelasan mengenai persyaratan dan tata cara pendirian rumah ibadah, proses perizinan rumah ibadat yang sering berlarutlarut, penyalahgunaan rumah tinggal atau bangunan lain yang difungsikan sebagai rumah ibadat, pendirian atau keberadaan rumah ibadat yang sesuai dengan prosedur yang berlaku dan tidak sesuai dengan aspirasi masyarakat setempat, pengaturan masing-masing pemerintah daerah yang masih seragam atau bahkan masih banyak pemerintah daerah yang belum memiliki regulasi untuk mengatur pendiriaan rumah ibadat, serta kurangnya komunikasi antar pemuka agama disuatu wilayah. ${ }^{35}$

\section{Pembatasan Pendirian Rumah lbadat}

Pendirian rumah ibadat tidak diatur dalam Konstitusi Indonesia. Pendirian rumah ibadat tidak pula diatur dalam suatu undang-undang. Pendirian rumah ibadat hanya diatur dalam Peraturan Bersama Menteri Agama dan Menteri Dalam Negeri Nomor 9 dan Nomor 8 Tahun 2006. Berdasarkan peraturan ini, pendirian rumah ibadah harus memenuhi berbagai persyaratan.

Peraturan Bersama Menteri Agama dan Menteri Dalam Negeri Nomor 9 dan Nomor 8 Tahun 2006 bersifat prosedur administratif. Apabila Peraturan Bersama Menteri Agama dan Menteri Dalam Negeri Nomor 9 dan Nomor 8 Tahun 2006 dipatuhi maka tidak akan timbul konflik. Oleh karena itu, Peraturan Bersama

\footnotetext{
${ }^{34}$ Ibid, hlm. 347.

${ }^{35} \mathrm{lbid}$, hlm. 346.
} 
Menteri Agama dan Menteri Dalam Negeri Nomor 9 dan Nomor 8 Tahun 2006 sejalan dengan prinsip hak asasi manusia. ${ }^{36}$

Peraturan Bersama Menteri Agama dan Menteri Dalam Negeri Nomor 9 dan Nomor 8 Tahun 2006 mengatur mengenai pembatasan tentang izin pendirian rumah ibadat. Alasan pembatasan karena pemeluk agama tidak dapat secara langsung membangun sebuah rumah ibadat sebagai manifestasi kepercayaannya tanpa izin dari pemerintah setempat, termasuk juga penduduk sekitar yang menghendaki pendirian rumah ibadat. ${ }^{37}$

Pembatasan pendirian rumah ibadat tidak bertentangan dengan prinsip kebebasan beragama. Dilihat dalam konteks kebebasan beragama dalam forum eksternum, negara dapat membatasi pelaksanaan pendirian rumah ibadat. Hal ini bisa dilihat dalam Pasal 18 Ayat (3) ICCPR, Pasal 9 Ayat (2) European Convention on Human Rights dan Pasal 12 Ayat (3) American Convention on Human Rights).Pasal 70 Undang-Undang Nomor 39 Tahun 1999 tentang Hak Asasi Manusia telah meligitimasi pembatasan ini. Pendirian rumah ibadah termasuk salah satu bentuk kebebasan beribadah yang dapat berbenturan dengan hakhak asasi lain, antara lain tentang ketertiban umum. ${ }^{38}$

Pembatasan kebebasan beragama diperkenankan berdasarkan Pasal 19 Ayat (3) ICCPR yang menyebutkan bahwa kebebasan untuk memanifestasikan agama atau kepercayaan dapat dibatasi hanya oleh hukum dan hanya diperlukan untuk melindungi keamanan masyarakat, kepentingan, kesehatan, atau moral, atau hak-hak fundamental lainnya. Pembatasan ini terhadap lima ketentuan, yaitu untuk perlindungan keamanan publik, untuk melindungi tatanan/ketertiban publik, untuk perlindungan kesehatan publik, untuk perlindungan moral, dan untuk melindungi hakhak dan kebebasan fundamental orang lain. ${ }^{39}$

Manfred Nowak \& Tanja Vospernik menjelaskan bahwa negara dapat membatasi kebebasan untuk memanifestasi agama atau keyakinan hanya jika ditentukan oleh hukum dan hanya jika karena salah satu dari lima alasan berikut: keselamatan umum, tatanan atau ketertiban masyarakat, moral publik, perlindungan hak serta kebebasan orang lain, dan jika pembatasan tersebut memang perlu dilakukan. Sebagai sebuah aturan umum maka batasan-batasan di atas haruslah tidak diskriminatif. ${ }^{40}$

Pasal 13, Pasal 14, Pasal 15 Peraturan Bersama Menteri Agama dan Menteri Dalam Negeri Tahun 2006 mengatur pembatasan pendirian rumah ibadah. Walaupun tampaknya bertentangan dengan Pasal 24 Ayat (1) dan Ayat (2) Undang-Undang Nomor 24 Tahun 1992 tentang Penataan Ruang, namun substansi masalah yang terdapat di dalam Peraturan Bersama Menteri Agama dan Menteri Dalam Negeri itu tidak bertentangan dengan Konstitusi. ${ }^{41}$

Pada prinsipnya, pembentukan Peraturan Bersama Menteri Agama dan Menteri Dalam

\footnotetext{
${ }^{36}$ Nela Sumika Putri, Pelaksanaan Kebebasan Beragama Di Indonesia (External Freedom) Dihubungkan Ijin Pembangunan Rumah Ibadah, Jurnal Dinamika Hukum, Volume 11, Nomor 2, Mei 2011, hlm. 232.

${ }^{37} \mathrm{Ibid}$.

${ }^{38} \mathrm{lbid}, \mathrm{hlm} .231$.

${ }^{39}$ Nela Sumika Putri, Pelaksanaan Kebebasan Beragama... Op. Cit., hlm. 230-231.

${ }^{40}$ Manfred Nowak \& Tanja Vospernik, dalam Tore Lindholm, W. Cole Durham Jr., \& Bahia G. Tahzib-Lie (ed.). Kebebasan Beragama dan Berkeyakinan: Seberapa Jauh?, Cetakan V, Penerjemah Rafael Edy Bosko \& M. Rifa'i Abduh, (Jakarta: Kanisius, 2014), hlm. 206.

${ }^{41} / \mathrm{bid}, \mathrm{hlm} .83$.
} 
Negeri Tahun 2006 memiliki semangat pengayoman. Pada bagian konsideran Peraturan Bersama Menteri Agama dan Menteri Dalam Negeri Tahun 2006 menyebutkan bahwa "Pemerintah mempunyai tugas untuk memberikan bimbingan dan pelayanan agar setiap penduduk dalam melaksanakan ajaran agamanya berlangsung dengan rukun, lancar, dan tertib (Bagian menimbang huruf c)". Adapun asas kebangsaan, kenusantaraan, dan Bhineka Tunggal lka tercermin di dalam huruf $h$ bagian konsideran Peraturan Bersama Menteri Agama dan Menteri Dalam Negeri tersebut yang menyebutkan bahwa "kerukunan umat beragama merupakan bagian penting dari kerukunan nasional (Bagian menimbang huruf $h$ )".

Sungguh disayangkan, kerukunan umat beragama hanya diatur setingkat peraturan menteri. Format peraturan itu, masih dirasakan belum kuat karena lemahnya aspek penegakan hukum yang terkandung didalamnya. Tidaklah keliru, jika A.Yewangoe berpendapat bahwa karena peraturan itu bukan produk lembaga negara maka penanggung jawab akhir dari peraturan itu ialah menteri-menteri yang bersangkutan. Untuk itu, perkembangan kehidupan beragama ke depan, pemerintah perlu memikirkan perumusan kerukunan umat beragama ke dalam sebuah undang-undang yang dapat diterima dan menjadi pijakan bersama bagi semua umat beragama. ${ }^{42}$

\section{Pendirian Rumah Ibadat}

Peraturan Bersama Menteri Agama dan Menteri Dalam Negeri Tahun 2006 diperlukan untuk menciptakan kondisi kerukunan umat beragama. Pasal 2 menyebutkan bahwa "Pemeliharaan kerukunan umat beragama menjadi tanggung jawab bersama umat beragama, pemerintahan daerah dan Pemerintah". Pasal 3 Ayat (1) Peraturan Bersama
Menteri Agama dan Menteri Dalam Negeri Tahun 2006 tersebut menyebutkan bahwa "pemeliharaan kerukunan umat beragama di provinsi menjadi tugas dan kewajiban gubernur". Penekanan terhadap fungsi aparatur pemerintahan di dalam pemeliharaan kerukunan umat beragama disebutkan di dalam ketentuan Pasal 4, Pasal 5, Pasal 6, dan Pasal 7. Adapun pelibatan masyarakat, yang menjelaskan peran dan fungsi masyarakat di dalam proses penciptaan kerukunan umat beragama, diatur di dalam lima pasal, yaitu Pasal 8, Pasal 9, Pasal 10, Pasal 11, dan Pasal 12, yang terdapat di dalam bab III.

Pasal 14 Peraturan Bersama Menteri Agama dan Menteri Dalam Negeri Nomor 9 dan Nomor 8 Tahun 2006 mengatur mengenai pendirian rumah ibadat. Pasal 13 Ayat (1) menyebutkan bahwa "Pendirian rumah ibadat didasarkan pada keperluan nyata dan sungguhsungguh berdasarkan komposisi jumlah penduduk bagi pelayanan umat beragama yang bersangkutan di wilayah kelurahan/desa". Pasal 13 Ayat (2) menyebutkan "Pendirian rumah ibadat sebagaimana dimaksud pada Ayat (1) dilakukan dengan tetap menjaga kerukunan umat beragama, tidak mengganggu ketenteraman dan ketertiban umum, serta mematuhi peraturan perundang-undangan". Pasal 13 Ayat (3) "Dalam hal keperluan nyata bagi pelayanan umat beragama di wilayah kelurahan/desa sebagaimana dimaksud Ayat (1) tidak terpenuhi, pertimbangan komposisi jumlah penduduk digunakan batas wilayah kecamatan atau kabupaten/kota atau provinsi".

Pasal 14 Ayat (1) menyebutkan bahwa "Pendirian rumah ibadat harus memenuhi persyaratan administratif dan persyaratan teknis bangunan gedung". Pasal 14 Ayat (2) menyebutkan bahwa "Selain memenuhi

\footnotetext{
${ }^{42}$ Ibid, hlm. 84.
} 
persyaratan sebagaimana dimaksud pada Ayat (1) pendirian rumah ibadat harus memenuhi persyaratan khusus meliputi: a. daftar nama dan Kartu Tanda Penduduk pengguna rumah ibadat paling sedikit 90 (sembilan puluh) orang yang disahkan oleh pejabat setempat sesuai dengan tingkat batas wilayah sebagaimana dimaksud dalam Pasal 13 Ayat (3); b. dukungan masyarakat setempat paling sedikit 60 (enam puluh) orang yang disahkan oleh lurah/kepala desa; c. rekomendasi tertulis kepala kantor departemen agama kabupaten/kota; dan d. rekomendasi tertulis FKUB kabupaten/kota". Pasal 14 Ayat (3) "Dalam hal persyaratan sebagaimana dimaksud pada Ayat (2) huruf a terpenuhi sedangkan persyaratan huruf $b$ belum terpenuhi, pemerintah daerah berkewajiban memfasilitasi tersedianya lokasi pembangunan rumah ibadat". ${ }^{43}$

Jika dilihat dari perspektif Pemerintah, dapat dipahami bahwa mengapa Pemerintah mencoba membuat suatu pengaturan terkait dengan pembangunan Rumah Ibadah melalui PBM pendirian Rumah Ibadah Tahun 2006, yaitu untuk menjaga ketertiban umum, mengingat Negara Indonesia adalah negara yang plural yang memiliki berbagai agama dan kepercayaan. Pada dasarnya ketentuan PBM ini adalah prosedur administratif, yang berarti sepanjang aturan dipenuhi seyogyanya tidak akan menimbulkan konflik. Pengaturan tentang izin pembangunan Rumah Ibadah ini dalam konteks HAM pada dasarnya diperkenankan sepanjang untuk mencegah kekacauan publik. $^{44}$

Peraturan Bersama Menteri Agama dan Menteri Dalam Negeri Nomor 9 dan 8 Tahun 2006 mengatur mengenai bentuk rumah ibadat.
Peraturan tersebut menjelaskan bahwa rumah ibadat adalah bangunan yang memiliki ciri-ciri tertentu yang khusus dipergunakan untuk beribadat bagi para pemeluk masing-masing agama secara permanen, tidak termasuk tempat ibadat keluarga. Rumah ibadat yang dimaksud adalah masjid (yang meliputi masjid agung, masjid besar, dan masjid jami') dalam agama Islam, gereja katedral atau gereja keuskupan dan gereja paroki dalam agama Katholik, gereja-gereja dewasa (denominasi) dalam agama Kristen yang pada umumnya memiliki otoritas tersendiri di bawah kepemimpinan pendetanya. Selain itu, rumah ibadat vihara dalam agama Budha, rumah ibadat pura dalam agama Hindu, rumah ibadat Litang/Klenteng dalam agama Khonghucu. ${ }^{45}$

Dalam Peraturan Bersama Menteri Agama dan Menteri Dalam Negeri tersebut, istilah rumah ibadat dibedakan dengan tempat ibadat keluarga yang fungsinya sebagai tempat suci/ibadat yang harus terpisahkan dengan aktifitas duniawi. Hal ini dimaksudkan untuk memenuhi hak setiap pemeluk agama dalam melaksanakan agamanya tanpa dikurangi sedikitpun. Adapun tempat ibadat keluarga yang dimaksud adalah musholla/langgar dalam agama Islam, rumah doa dalam agama Kristen, kapel dalam agama Katholik, sanggah/mrajan dalam agama Hindu, cetya dalam agama Budha, dan co bio/cong bio dalam agama Khonghucu. ${ }^{46}$

\section{Penyelesaian Perselisihan Pendirian Rumah Ibadat}

Terbitnya Peraturan Bersama Menteri Agama dan Menteri Dalam Negeri (PBM) Nomor 9 Tahun 2006 bukan berarti selesai

\footnotetext{
${ }^{43}$ Nella Sumika Putri, Pelaksanaan Kebebasan Beragama...Op. Cit., hlm. 231.

${ }^{44}$ Ibid, hlm. 13.

${ }^{45}$ Lihat, Bab I Pasal 1 ayat (3) Peraturan Bersama Mentri Agama dan Menteri Dalam Negeri Nomor 9 dan Nomor 8 Tahun 2006.

${ }^{46}$ Sulaiman, Problematika Pendirian Rumah Ibadat di Pati, Jawa Tengah, Analisa Journal of Social Science and Religion, Volume 22, Nomor 02, Desember 2015, hlm, 188.
} 
persoalan, karena pada tataran implementasi masih dijumpai masalah. The Wahid Institute melaporkan, konflik seputar rumah ibadah muncul, seperti pada 2008 tercatat 21 kasus, 12 diantaranya adalah penolakan pendirian rumah ibadah. CRCS UGM melaporkan pada tahun yang sama mencatat ada 14 kasus konflik rumah ibadah, 8 diantaranya merupakan penolakan dan pelarangan pendirian hingga pembongkaran rumah ibadah. Halili dan Naipospos mencatat ada 375 kasus konflik berkaitan dengan rumah ibadah, 307 kasus merupakan kasus gangguan terhadap rumah dan tempat ibadah, sedangkan 68 kasus berupa pelanggaran pendirian rumah ibadat. Meski pemerintah telah mengeluarkan regulasi untuk menekan konflik, namun kenyataannya konflik terus terjadi. ${ }^{47}$

Pada umumnya, konflik mengenai pendirian rumah ibadat terjadi karena beberapa permasalahan, diantaranya: persyaratan pendirian rumah ibadat, perizinan rumah ibadat, penyalahgunann rumah tinggal yang difungsikan sebagai rumah ibadat, pendirian rumah ibadat yang tidak sesuai dengan aspirasi masyarakat setempat, pemerintah daerah yang belum memiliki peraturan untuk mengatur pendirian rumah ibadat, dan lain-lain. ${ }^{48}$

Dalam pendirian rumah ibadat, masalah yang sering muncul diseputarnya, antara lain: tidak ada izin/rekomendasi dari Kantor Kementerian Agama kabupaten/kota, protes terhadap pemanfaatan rumah tinggal sebagai tempat ibadat secara rutin, penolakan pendirian rumah ibadat, pendirian rumah ibadat tanpa rekomendasi dari FKUB, keluhan kesulitan pendirian rumah ibadat bagi pemeluk agama minoritas, arogansi minoritas atas pendirian rumah ibadat, manipulasi data dan tanda tangan sebagai persyaratan pengguna dan/atau dukungan pendirian rumah ibadat, administrasi pemerintah yang kurang akurat, penolakan pendirian rumah ibadat oleh masyarakat, pencabutan IMB oleh pemerintah daerah tertentu dengan alasan dan pertimbangan keresahan, gangguan keagamaan dan ketertiban masyarakat. ${ }^{49}$

Berbagai persoalan di sekitar pendirian rumah ibadat masih sering terjadi di beberapa daerah, walaupun intensitasnya sudah jauh berkurang sejak diberlakukannya Peraturan Bersama Menteri Agama dan Menteri Dalam Negeri Nomor 9 dan 8 Tahun 2006. Pernyataan ini berdasarkan hasil evaluasi tahun pertama pelaksanaan PBM, bahwa kondisi kehidupan beragama di Indonesia semakin kondusif, yang salah satunya dipengaruhi oleh keberadaan peraturan tentang rumah ibadat. Hal ini kemudian mendapatkan konfirmasi-positif dari hasil penelitian yang dilakukan oleh Puslitbang Kehidupan Keagamaan tahun 2007. ${ }^{50}$

Ibnu Hasan Muchtar menyimpulkan bahwa disosialisasikannya Peraturan Bersama Menteri Agama dan Menteri Dalam Negeri (PBM) Nomor 9 Tahun 2006 tentang Pedoman Pelaksanaan Tugas Kepala Daerah/Wakil Kepala Daerah dalam Pemeliharaan Kerukunan Umat Beragama, Pemberdayaan Forum Kerukunan Umat Beragama, dan Pendirian Rumah Ibadat ini telah berpengaruh secara nyata terhadap upaya pemeliharaan kerukunan umat beragama, dengan pengaruh

${ }^{47}$ Ibid, hlm. 11.

${ }^{48}$ Nur Ahmad, Pesan Dakwah Dalam...Op. Cit., hlm. 345-346.

${ }^{49}$ M. Yusuf Asry (Ed.), Pendirian Rumah Ibadat di Indonesia Pelaksanaan PBM Nomor 9 dan 8 Tahun 2006, (Jakarta: Badan Litbang dan Diklat, Kementerian Agama RI, 2011), hlm. 4.

${ }^{50}$ Ibnu Hasan Muchtar, Dilema Pendirian Rumah Ibadat: Studi Pelaksanaan PBM No. 9 dan 8 Tahun 2006 di Kota Bekasi, Harmoni Jurnal Multi Kultural \& Multi Religius, Volume IX, Nomor 35, Juli-September 2010, hlm. 99. 
sebesar $17,4 \%$. Meski angka ini terlihat kecil (hanya $17,4 \%$ ), namun sesungguhnya sebagai salah satu faktor dari 11 faktor yang dapat menyebabkan ketidakrukunan, permasalahan di sekitar pendirian rumah ibadat menjadi sangat penting dan maka keberadaan peraturan ini menjadi cukup signifikan. ${ }^{51}$

Sebenarnya pemerintah sudah mengantisipasi terjadinya konflik antar umat beragama khususnya perusakan tempat ibadah dengan mengeluarkan regulasi sejak lama, yaitu dengan keluarnya SKB pada 1969. Akan tetapi, Surat Keputusan Bersama (SKB) No. 1/Ber/ MDN-MAG/1969 ini dianggap terlalu diskriminatif dan tidak rincinya pegaturan mengenai pendirian rumah ibadat. Oleh karena itu, Pemerintah mengeluarkan Peraturan Bersama Menteri Agama dan Menteri Dalam Negeri (PBM) Nomor 9 Tahun 2006. Ali Fauzi mencatat sejak 1969-2006 terjadi lebih dari 1000 kasus konflik pendirian rumah ibadat terutama berkaitan dengan pendirian gereja. ${ }^{52} \mathrm{PMB} 9$ dan 8 Tahun 2006 mengatur tiga hal, yaitu pembinaan kerukunan umat beragama melalui pembentukan Forum Kerukunan Umat Beragama, prosedur pendirian rumah ibadat, dan penyelesaian bila terjadi konflik. ${ }^{53}$

Ada perbedaan yang cukup mendasar antara Surat Keputusan Bersama Dua Menteri No. 01/BER/mdn-mag/1969 dengan Peraturan Bersama Menteri Agama dan Menteri Dalam Negeri (PBM) Nomor 9 Tahun 2006 dan Nomor 8 Tahun 2006. Jika Surat Keputusan Bersama Dua Menteri Nomor 01/BER/mdn-mag/1969 mengatur kerukunan umat beragama secara umum maka Peraturan Bersama Menteri Agama dan Menteri Dalam Negeri (PBM)
Nomor 9 Tahun 2006 dan Nomor 8 Tahun 2006 mengatur lebih detail mengenai kewenangan pemeliharaan kerukunan umat beragama, mekanisme perizinan rumah ibadah, dan penyelesaian jika terjadi konflik. Peraturan Bersama Menteri Agama dan Menteri Dalam Negeri Nomor 9 Tahun 2006 dan Nomor 8 Tahun 2006 terdiri atas 30 Pasal yang dibagi dalam 10 bab, yakni (1) Ketentuan Umum; (2) Tugas Kepala Daerah; (3) Tugas dan Peran Forum Kerukunan Umat Beragama (FKUB); (4) Pendirian Rumah Ibadah (5) Rumah Ibadah Sementara; (6) Izin Sementara Pemanfaatan Gedung; (7) Penyelesaian Perselisihan; (8) Pengawasan dan Pelaporan; (9) Sumber Dana FKUB; dan (10) Mekanisme Peralihan dan Penutup. ${ }^{54}$

Pemeliharaan kerukunan beragama merupakan tanggung jawab bersama antara pemerintah dan umat beragama. Pemerintah diwakili gubernur atau bupati/walikota untuk tingkat kabupaten/kota. Sementara aspirasi umat beragama diwakili oleh pemimpin agama 'resmi' yang tergabung dalam Forum Kerukunan Umat Beragama (FKUB). Anggota FKUB berjumlah 21 orang untuk tingkat provinsi dan 17 orang untuk tingkat kabupaten atau kota. Kuota perwakilan masing-masing agama berdasarkan perbandingan jumlah pemeluk agama masing-masing daerah, minimal satu agama diwakili oleh satu orang. Peraturan Bersama Menteri Agama dan Menteri Dalam Negeri (PBM) Nomor 9 Tahun 2006 dan Nomor 8 Tahun 2006, antara lain mengatur pendirian rumah ibadah wajib memenuhi syarat, yaitu (1) Daftar nama dan Kartu Tanda Penduduk (KTP) 90 orang pengusul rumah ibadah yang disahkan

51 lbid.

${ }^{52}$ Ihsan Ali-Fauzi, dkk, Kontroversi Gereja di Jakarta, (Yogyakarta: CRCS Universitas Gajah Mada, 2011), hlm. 13.

${ }^{53}$ M. Agus Noorbani, Pendirian Rumah Ibadat...Op.Cit., hlm. 9-22.

${ }^{54}$ Ihsan Ali-Fauzi, dkk., Kontroversi Gereja...Op. Cit., hlm, 36. 
oleh pejabat sesuai dengan batas wilayah setempat, (2) KTP 60 orang warga setempat yang disahkan oleh kepala desa atau lurah, (3) Rekomendasi tertulis dari kantor Departemen Agama kabupaten atau kota setempat, (4) Rekomendasi dari FKUB kabupaten setempat. Rekomendasi tersebut harus didasarkan pada musyawarah mufakat dan tidak dapat dilakukan dengan voting. ${ }^{55}$

Apabila persyaratan berupa dukungan dari masyarakat sekitar tidak terpenuhi, pemerintah wajib mencarikan lokasi baru. Menyangkut bangunan lain yang digunakan sebagai rumah ibadah sementara terlebih dahulu harus mendapatkan izin dari pemerintah kabupaten atau kota. Izin tersebut dapat keluar jika kantor Departemen Agama dan FKUB telah mengeluarkan surat rekomendasi. ljin bangunan sebagai rumah ibadah sementara hanya berlaku sampai dua tahun. Jika terjadi konflik di seputar pendirian rumah ibadah maka pertama-tama diselesaikan melalui musyawarah mufakat bersama masyarakat setempat. Jika tidak tercapai maka pemerintah kabupaten atau kota wajib memfasilitasi musyawarah secara adil dan netral. Manakala mediasi pemerintah kabupaten atau kota menemui jalan buntu, penyelesaian akhir ditetapkan melalui pengadilan setempat. ${ }^{56}$

Peraturan Bersama Menteri Agama dan Menteri Dalam Negeri Nomor 9 dan Nomor 8 Tahun 2006 mengatur tentang penyelesaian perselisihan mengenai rumah ibadat. Pasal 21 Peraturan Bersama Menteri Agama dan Menteri Dalam Negeri Nomor 9 dan 8 Tahun 2006. Pasal 21 Ayat (1) menyatakan bahwa "Perselisihan akibat pendirian rumah ibadat diselesaikan secara musyawarah oleh masyarakat setempat". Pasal 21 Ayat (2) menyatakan bahwa
"Dalam hal musyawarah sebagaimana dimaksud pada Ayat (1) tidak dicapai penyelesaian perselisihan dilakukan oleh bupati/ walikota dibantu kepala kantor departemen agama kabupaten/kota melalui musyawarah yang dilakukan secara adil dan tidak memihak dengan mempertimbangkan pendapat atau saran FKUB kabupaten/kota". Selanjutnya, Pasal 21 Ayat (3) menyatakan bahwa "Dalam hal penyelesaian perselisihan sebagaimana dimaksud pada Ayat (2) tidak dicapai, penyelesaian perselisihan dilakukan melalui Pengadilan setempat".

Apabila dicermati keseluruhan dari substansi Peraturan Bersama Menteri Agama dan Menteri Dalam Negeri Nomor 9 Tahun 2006 maka dilihat dari aspek aturan administratif, peraturan tersebut telah memberikan suatu keadilan. Meskipun aturan administratif telah terpenuhi, bukan berarti dengan pemeluk agama dapat dengan mudah melaksanakan pembangunan rumah ibadat. ${ }^{57}$

Apabila dicermati permasalahan pendirian rumah ibadat, sebenarnya permasalahan terjadi karena penganut agama keliru memahami peruntukan kebebasan beragama yang dijamin dalam UUD 1954. Hal ini bisa dimaklumi karena UUD 145 tidak menjelaskan secara terperinci peruntukan kebebasan beragama, yang meliputi kebebasan menganut agama, kebebasan mengamalkan agama, dan kebebasan mengembangkan agama. Oleh karena itu, tidak tepat jika penganut agama membenarkan tindakannya mendirikan rumah ibadat karena alasan kebebasan mengamalkan agama.

Memang tidak ada peraturan yang membatasi kebebasan beragama, akan tetapi terdapat peraturan yang membatasi kebebasan

\footnotetext{
${ }^{55}$ Ibid.

${ }^{56}$ Ibid.

${ }^{57}$ Nella Sumika Putri, Pelaksanaan Kebebasan Beragama ..... Op. Cit., hlm. 234.
} 
mendirikan rumah ibadat untuk tujuan mengamalkan agama. Para penganut agama bebas mengamalkan agamanya, akan tetapi para penganut agama tidak bebas mendirikan rumah ibadat yang bisa mengganggu penganut agama lain.

Bagaimanapun, isu mengenai pendirian rumah ibadat merupakan isu yang sensitif. Pemerintah tidak boleh menganggap ringan permasalahan ini. Pemerintah perlu mencari jalan penyelesaian permasalahan ini karena hal ini berpotensi menganggu keharmonisan antara penganut agama dan bisa memecah belah persatuan bangsa. Jika pemerintah tidak mengambil langkah serius mencari jalan penyelesaian maka dikhawatirkan akan terjadi konflik dikemudian hari. Oleh karena itu, pemerintah Indonesia perlu meningkatkan level pengaturan rumah ibadat menjadi undangundang. Pemerintah perlu mengesahkan suatu undang-undang berkaitan pendirian rumah ibadat yang wajib dipatuhi oleh semua penganut agama agar tidak terjadi konflik antar penganut agama.

\section{Penutup}

Jika SKB Tahun 1969 mengatur kehidupan kerukunan beragama secara umum maka Peraturan Bersama Menteri Agama dan Menteri Dalam Negeri Nomor 9 Tahun 2006 dan Nomor 8 Tahun 2006 mengatur secara khusus dua hal yang saling berkaitan pembinaan kerukunan umat beragama melalui pembentukan Forum Kerukunan Umat Beragama dan prosedur pendirian rumah ibadat. Peraturan Bersama Menteri Agama dan Menteri Dalam Negeri ini lebih rinci mengatur kewenangan pemeliharaan kerukunan umat beragama, mekanisme perizinan rumah ibadat, dan penyelesaian bila terjadi konflik.

Terbitkannya Peraturan Bersama Menteri Agama dan Menteri Dalam Negeri tersebut bukan berarti seluruh persoalan pendirian rumah ibadah selesai, karena masih harus diuji pada tingkat implementasi. Regulasi rumah ibadah bukanlah masalah yang berdiri sendiri, tetapi terkait dengan masalah-masalah lain, misalnya soal penyiaran agama dan bantuan asing. Pemerintah mengeluarkan Peraturan Bersama Menteri Agama dan Menteri Dalam Negeri tersebut sebagai upaya meminimalisir konflik pendirian rumah ibadat.

Keberadaan regulasi yang baru tersebut diharapkan mampu mencegah potensi konflik berkaitan dengan pendirian rumah ibadah. Potensi konflik muncul karena beberapa persoalan, diantaranya persyaratan dan tata cara pendirian rumah ibadah, proses perizinan rumah ibadat yang sering berlarut-larut, penyalahgunaan rumah tinggal yang difungsikan sebagai rumah ibadat dan sebagainya.

Apabila dicermati keseluruhan dari substansi Peraturan Bersama Menteri Agama dan Menteri Dalam Negeri Nomor 9 Tahun 2006 maka dilihat dari aspek aturan administratif, peraturan tersebut telah memberikan suatu keadilan. Meskipun aturan administratif telah terpenuhi, bukan berarti dengan pemeluk agama dapat dengan mudah melaksanakan pembangunan rumah ibadat.

Peraturan Bersama Menteri Agama dan Menteri Dalam Negeri Nomor 9 Tahun 2006 mengatur penyelesaian masalah melalui jalur musyawarah dan pengadilan. Apabila perselisihan mengenai rumah ibadat tidak bisa diselesaikan melalui jalur musyawarah maka perselisihan mengenai rumah ibadat bisa diselesaikan melalui jalur pengadilan. Apabila kedua jalur penyelesaian tersebut tidak juga bisa menyelesaikan perselisihan maka perlu ditingkatkan level pengaturan rumah ibadat menjadi undang-undang. Problem pendirian rumah ibadat dapat diselesaikan secara komprehensif jika terdapat suatu undang- 
undang yang mengatur tentang pendirian rumah ibadat. Solusi komprehensif ini perlu dilakukan agar tidak terjadi lagi konflik dan disharmonis antara penganut berbagai agama.

\section{Referensi}

Abdi Kurnia Djohan. 2010. Analisis dan Perbandingan Pengaturan Kerukunan Umat Beragama di Indonesia. Jakarta: Universitas Indonesia.

Ahmad Subakir dkk. 2010. Potret Buram Kebebasan Beragama. Yogyakarta: Nadi Pustaka-STAIN Kediri Press.

Ahmad Sukadja. 1995.Piagam Madinah dan Undang-Undang Dasar 1945: Kajian Perbandingan tentang Dasar Hidup Bersama dalam Masyarakat yang Majemuk. Jakarta: Universitas Indonesia Press.

Ahsanul Khalikin. 2001. Peta Kerukunan Di DKI Jakarta. Jakarta: Balitbang dan Diklat.

Aslati,Optimalisasi Peran FKUB Dalam Menciptakan Toleransi Beragama di Kota Pekanbaru. Jurnal Toleransi: Media Komunikasi Umat Beragama. Volume 6. Nomor 2. Juli-Desember 2014.

Abdurrahman Mas'ud dkk (ed). 2011. Kerukunan Umat Beragama dalam Sorotan: Refleksi dan Evaluasi 10 Tahun Kebijakan dan Program Pusat Kerukunan Umat Beragama. Jakarta: Sekretariat Jenderal Kementerian Agama.

Baehaqi Imam. 2005. Agama dan Relasi Sosial. Yogyakarta: LKiS.

Burhan Ashofa. 2006. Metode Penelitian Hukum. Jakarta: Rineka Cipta.

Haidlor Ali Ahmad (Ed). 2013. Survey Nasional Kerukunan Umat Beragama di Indonesia. Jakarta: Puslitbang
Kehidupan Keagamaan Badan Litbang dan Diklat Kementerian Agama RI.

Ihsan Ali-Fauzi. dkk. 2011.Kontroversi Gereja di Jakarta. Yogyakarta: CRCS Universitas Gajah Mada.

James Hasting (ed). tt. Encyclopedia of Religion and Ethics. Volume XI. New York: Charles Scribner's Son.

Johnny Ibrahim. 2006.Teori dan Metodologi Penelitian Hukum Normatif. Surabaya: Bayu Media Publishing.

Kustini. 2009. Efektifitas Sosialisasi PBM No. 9 dan 8 Tahun 2006. Jakarta: Balitbang Departemen Agama RI.

M. Agus Noorbani. Pendirian Rumah Ibadat di Kota Cirebon Pasca Pemberlakuan Peraturan Bersama Menteri Agama dan Menteri Dalam Negeri Nomor 9 dan 8 Tahun 2006. Harmoni Jurnal Multi-kultural \& Multi Religius. Volume 14. Desember 2015.

M. Yusuf Asry (Ed.). 2011. Pendirian Rumah Ibadat di Indonesia Pelaksanaan PBM Nomor 9 dan 8 Tahun 2006. Jakarta: Badan Litbang dan Diklat, Kementerian Agama RI.

Muhith A. Karim, dkk. 2001. Peta Kerukunan Jawa Timur. Jakarta: Balitbang dan Diklat Depag.

Nela Sumika Putri. Pelaksanaan Kebebasan Beragama di Indonesia (External Freedom) Dihubungkan ljin Pembangunan Rumah Ibadah. Jurnal Dinamika Hukum. Volume 11. Nomor 2. Mei 2011.

Nur Ahmad. Pesan Dakwah Dalam Menyelesaikan Konflik Pembangunan Rumah Ibadah (Kasus Pembangunan Rumah Ibadah antara Islam dan Kristen Desa Payaman). Jurnal Fikrah. Volume 1. Nomor 2. JuliDesember 2013. 
Peter Mahmud Marzuki. 2011. Penelitian Hukum. Jakarta: Kencana Prenada Media.

Soejono Soekanto dan Sri Mamudji. 2009. Penelitian Hukum Normatif Suatu Tinjauan Singkat. Cetakan XI. Jakarta: Raja Grafindo Persada.

Sulaiman. Problematika Pendirian Rumah Ibadat di Pati, Jawa Tengah. Analisa Journal of Social Science and
Religion. Volume 22. Nomor 02. Desember 2015.

Titik Suwariyati. 2001.Peta Kerukunan di Yogyakarta. Jakarta: Balitbang dan Diklat.

Tore Lindholm, W. Cole Durham Jr., \& Bahia G. Tahzib-Lie (ed.). 2014. Kebebasan Beragama dan Berkeyakinan: Seberapa Jauh?. Cetakan V. Penerjemah Rafael Edy Bosko \& M. Rifa'i Abduh. Jakarta: Kanisius. 